\title{
Synthesis of Substituted
} 1-Thiocyanatobutadienes and their Application in a Diels-Alder/[3,3] Sigmatropic Rearrangement Tandem Reaction

\author{
Sébastien Lanaspèze and Reinhard Neier* \\ Institute of Chemistry, University of Neuchâtel, CH-2007 Neuchâtel, Switzerland \\ Received August 9, 2004; accepted August 30, 2004 \\ Published online January 24, 2005 (C) Springer-Verlag 2005
}

\begin{abstract}
Summary. The retrosynthetic analysis of Ibogamine, a natural psychotropic alkaloid with exceptional anti-addictive properties found in both enantiomeric forms, requires an efficient access to a racemic cyclohexene. This cyclohexene can be obtained via the sequence Diels-Alder/[3,3] sigmatropic rearrangement reaction starting from substituted 1-thiocyanatobutadienes. An efficient synthesis of the enone, a stable precursor of 1-thiocyanatobutadienes, is reported. Enolisation of this enone was studied to find the optimal conditions to get the desired 1-thiocyanatobutadienes with good Z-selectivity.
\end{abstract}

Keywords. Enols; Ibogamine; Rearrangements; Tandem reactions; Total synthesis.

\section{Introduction}

The number of synthetic steps in a total synthesis strongly influences the efficiency. An attractive way to reduce the length of a synthetic pathway is to combine several transformations into one-pot reactions so called tandem, domino, or cascade reaction [1-3]. The tandem process Diels-Alder reaction/[3,3] sigmatropic rearrangement combines two well-known pericyclic reactions in one single synthetic step, which allows to obtain interesting synthetic building blocks efficiently [4]. Starting from (E)-1-thiocyanatobuta-1,3-diene (1) and acryloyl chloride led to a cis/trans 85:15 mixture of diastereoisomers of 1,4-substituted cyclohexene 3 in $84 \%$ yield [5] (Scheme 1). The cyclohexene 3 is a precursor for the preparation of the skeleton of Iboga-type alkaloids. The isothiocyanate $\mathbf{3}$ can be easily transformed in three steps to the 2-azabicyclo[2.2.2]oct-5-ene 4 [5] (Scheme 1). This

\footnotetext{
* Corresponding author. E-mail: reinhard.neier@unine.ch
} 


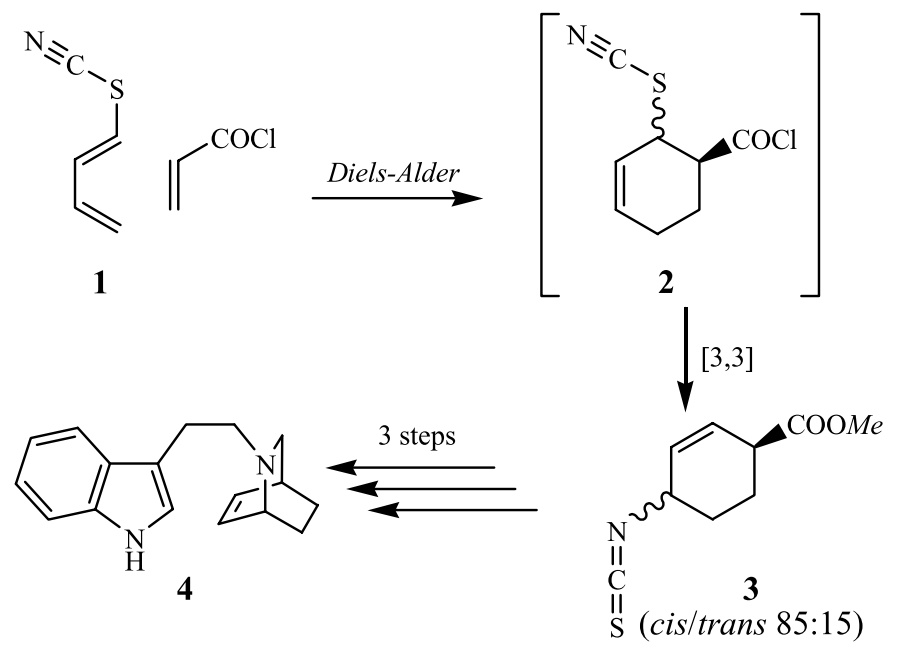

Scheme 1

bicyclic compound has been used by Trost et al. for the synthesis of desethylibogamine (5) [6, 7].

Ibogamine (6a), as other Iboga-type alkaloids, has been isolated from an African plant Tabernanthe iboga [8], which has well-known psychotropic activities. Studies on rodents have proven that $6 \mathbf{a}$ shows exceptional multi-drug anti-addictive properties [8-10]. Unfortunately, despite the encouraging results described by Lotsof [11] about treatment of opioid withdrawal with ibogaine (6b) on human patients, systematic clinical studies have not been carried out. Since the first total synthesis of 6a by Büchi [12] in 1965, eleven other total synthesis have been reported [7,13-21] but none of them is cost- and material-efficient enough to allow the production of this compound or of derivatives of this compound in large scale industrial production.

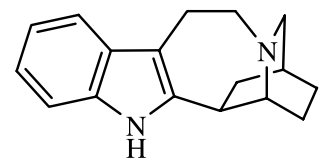

5 (+/-)-Desethylibogamine

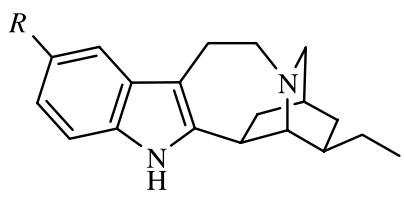

6a $R=\mathrm{H}:(+/-)-$ Ibogamine

6b $R=\mathrm{OMe}$ : (+/-)-Ibogaine

In most of the reported total syntheses of ibogamine (6a), the crucial step is the formation of the $\mathrm{C}-\mathrm{C}$ bond between the carbons $\mathrm{C}(2)$ corresponding to the $\alpha$-position of the indole ring and $\mathrm{C}(16)$ one of the $\alpha$-positions of the bridgehead carbon connected to the $\mathrm{N}$-atom. In the total synthesis reported by Trost et al. this crucial $\mathrm{C}-\mathrm{C}$ bond was formed using a palladium-catalysed Heck-type $\mathrm{C}-\mathrm{C}$ coupling, in the presence of stoechiometric amounts of a silver salt [7]. The goal of our studies is to develop an alternative procedure for the synthesis of the strategic $\mathrm{C}-\mathrm{C}$ bond avoiding use of stoechiometric quantities of a silver salt. Introducing a triflate protected enolate on carbon $\mathrm{C}(16)$ should allow to test different catalytic $\mathrm{C}-\mathrm{C}$ 


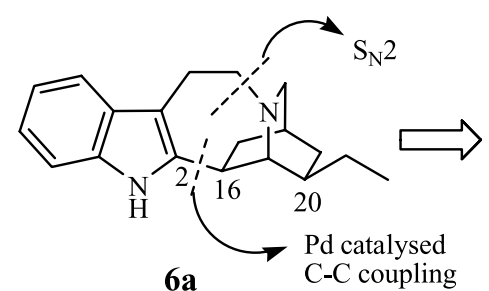<smiles>[M]c1c(CCOC)c2ccccc2n1[Tl]</smiles><smiles>CCC1CN2CC(O)C1C2O</smiles>

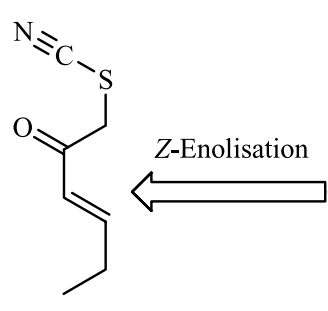

11<smiles>[R]O/C(C=CCC)=C\SC#N</smiles>

10

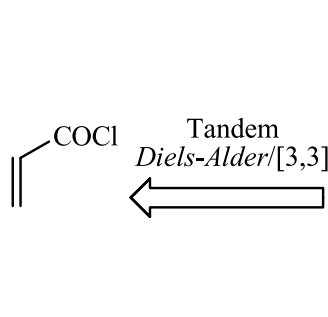

Scheme 2<smiles>CC[C@H]1C[C@H](C(=O)OC)C=C(O)[C@@H]1N=C=S</smiles>

coupling conditions. Ibogamine (6a), contrary to the model compound desethylibogamine (5), possesses an additional ethyl group in a pseudo-equatorial position on carbon $\mathrm{C}(20)$. The retrosynthetic analysis of $\mathbf{6 a}$ based on the formation of the strategic $\mathrm{C}-\mathrm{C}$ bond described above leads to two major building blocks of similar size: the indole derivative $7\left(M=\mathrm{B}(\mathrm{OH})_{2}, \mathrm{ZnCl}\right)$ and the isoquinuclidine ring rac-8. We propose to obtain the isoquinuclidine ring rac-8 via our tandem process DielsAlder reaction/[3,3] sigmatropic rearrangement starting from the 2,4-substituted 1-thiocyanatobuta-1,3-diene 10. In this paper the synthesis of diene $\mathbf{1 0}$ via a $Z$-enolisation of the enone $\mathbf{1 1}$ is reported and the stereoselectivity of this enolisation is studied.

\section{Results and Discussions}

The initial step of the synthesis of enone $\mathbf{1 1}$ is the preparation of the phosphorane $\mathbf{1 3}$. According to the procedure described by Hudson et al. [22], we started our synthesis from the highly toxic, commercially available 1,3-dichloroacetone 12. According to the literature procedure the intermediate salt formed from the $\mathrm{S}_{\mathrm{N}} 2$ reaction between the dichloroketone and triphenylphosphine was isolated in $85 \%$ yield. The salt was then deprotonated in a separate step to get the ylide 13. To improve the yield and to reduce the time of exposure to toxic $\alpha$-chloroketones, we developed a one-pot

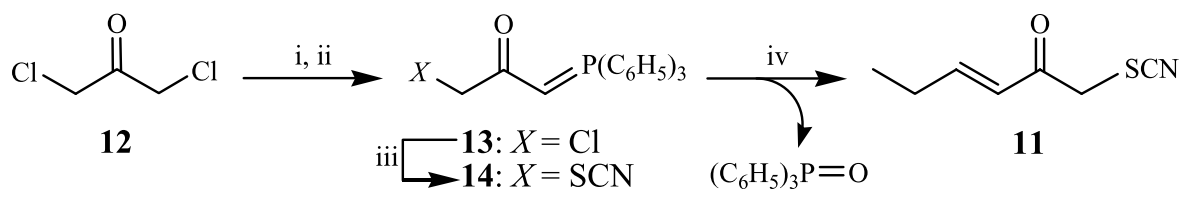

Reagents and conditions: (i) $\mathrm{PPh}, \mathrm{THF}$, reflux, 4h; (ii) $\mathrm{Na}_{2} \mathrm{CO}_{3}, \mathrm{MeOH}, \mathrm{rt}, 30 \mathrm{~min}, 97 \%$; (iii) $\mathrm{KSCN}$, $\mathrm{KI}_{\text {cat }}, E t \mathrm{OH}, 55^{\circ} \mathrm{C}, 5 \mathrm{~h}, 96 \%$; (iv) propionaldehyde, $40^{\circ} \mathrm{C}, 6 \mathrm{~h}, 70 \%$ 


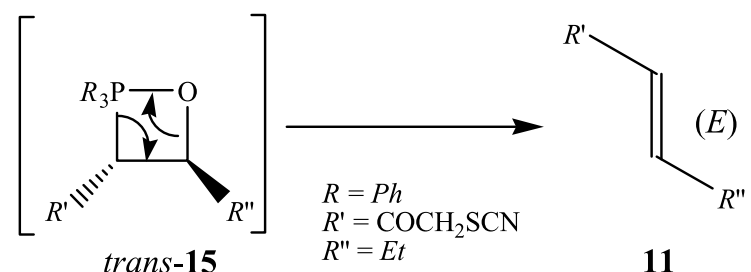

Scheme 4

process. Using this one-pot procedure the ylide $\mathbf{1 3}$ could be isolated in almost quantitative yield. Displacement of the first chlorine atom of 1,3-dichloroacetone $\mathbf{1 2}$ by triphenylphosphine was monitored by the disappearance of the ${ }^{31} \mathrm{P}$ signal of triphenylphosphine $\left(\delta_{\mathrm{P}}=-4.4 \mathrm{ppm}\right)$ in its ${ }^{31} \mathrm{P}$ NMR (Scheme 3$)$. The second $\mathrm{S}_{\mathrm{N}} 2$ reaction replacing the chloride by nucleophilic attack of the sulphur atom of the thiocyanate anion was carried out in ethanol. In order to accelerate the reaction, the presence of a catalytic quantity of iodide was needed, as has been reported by Sapi et al. [23]. Thus, the thiocyanate $\mathbf{1 4}$ was obtained in very good yield and satisfactory purity so that the raw material could be used in the following step without further purification.

The Wittig reaction was assumed to be $E$-selective due to the stabilisation of ylide 14 by the adjacent carbonyl group. As assumed the $E$-enone 11 was obtained as a consequence of the thermodynamic equilibrium between the more stable transoxaphosphetane $\mathbf{1 5}$ and its cis-diastereoisomer during the Wittig reaction (Scheme 4).

Propionaldehyde was both the solvent and the reactant of our Wittig reaction. The progress of the reaction was monitored by the growth of the ${ }^{31} \mathrm{P}$ signal of triphenylphosphine oxide $\left(\delta_{\mathrm{P}}=30.1 \mathrm{ppm}\right)$ in ${ }^{31} \mathrm{P}$ NMR. The $\alpha, \beta$-unsaturated ketone $\mathbf{1 1}$ is probably undergoing unwanted polymerisations, which make the purification difficult. Thus, after filtration on a short silica gel column, the enone $\mathbf{1 1}$ was purified by a bulb-to-bulb distillation $\left(100^{\circ} \mathrm{C}, 10^{-1} \mathrm{mbar}\right)$. By this straight forward three-steps process enone 11 could be obtained in $65 \%$ total yield starting from 1,3-dichloroacetone $\mathbf{1 2}$.

In order to optimize the reaction conditions for the enolisation model $\mathbf{1 6} \mathbf{b}$ was chosen. Synthesis of thiocyanate $\mathbf{1 6} \mathbf{b}$ was carried out using a similar procedure as for the synthesis of $\mathbf{1 4}$ starting from commercially available phenacyl chloride $\mathbf{1 6 a}$ (Scheme 5).

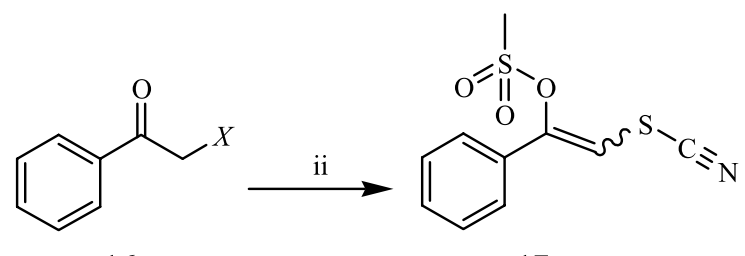

16

17

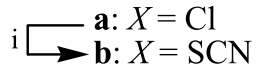
$(Z) /(E) 99: 1$

Reagents and conditions: (i) $\mathrm{KSCN}, \mathrm{KI}_{\text {cat }}$, Et OH, rt, $4 \mathrm{~h}, 86 \%$; (ii) $M s \mathrm{Cl}, E t_{3} \mathrm{~N}, \mathrm{CH}_{2} \mathrm{Cl}_{2}, \mathrm{rt}, 45 \mathrm{~min}, 40 \%$

Scheme 5 

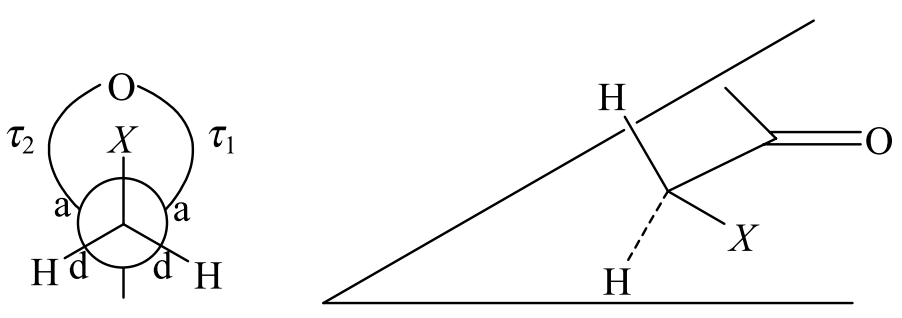

Scheme 6

The enolisation of $\alpha$-halogenoketones usually leads to the kinetic ( $Z$ )-diastereoisomer [24]. The $\alpha$-thiocyanatoketones can be viewed as pseudohalogen analogues of $\alpha$-halogenoketones. The stereoselectivity of the enolisation can be explained using $\tau$-bonds, also called "banana" bonds or bent bonds [25-28]. Using a Newman projection to describe the most stable ground state conformation of the $\alpha$-halogenoketone, the strongest electron withdrawing substituent in the $\alpha$-position of the carbonyl group (the halogen or the pseudohalogen) has to be in a syn-coplanar position relative to the $\mathrm{C}-\mathrm{O} \tau$-bond (Scheme 6 ). In this conformation all bonds are staggered, the two hydrogen atoms, which are the best donor atoms, are in a anti-periplanar position compared to the two strongly electron attracting $\mathrm{C}-\mathrm{O} \tau$-bonds (Scheme 6).

Having the precursors for our enolates in hand, we studied the stereoselectivity of the enolisation process of our enone $\mathbf{1 1}$ under thermodynamic conditions, using triethylamine or Hünig's base. With our model compound 16b, an excellent stereoselectivity of the enolisation was observed under our experimental conditions. Compound 17 was obtained as a $(Z) /(E)$-mixture with a diastereoselectivity of

Table 1. Study of stereoselectivity of the enolisation of enone 11 under thermodynamic conditions

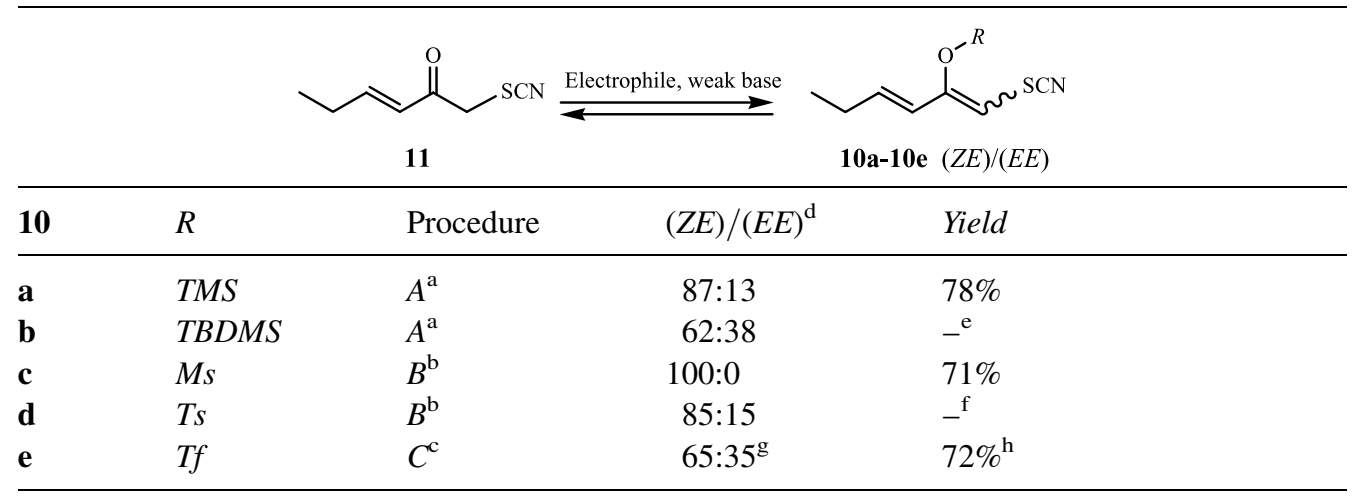

${ }^{a}$ Procedure $A$ : 2.2 eq triethylamine +2 eq electrophile +1 eq enone $\mathbf{1 1}$ in ether as solvent at rt for $1 \mathrm{~h}$; b procedure B: 2-10 eq triethylamine $+1.2-5$ eq electrophile +1 eq enone 11 in $\mathrm{CH}_{2} \mathrm{Cl}_{2}$ as solvent at $0^{\circ} \mathrm{C}$ for $30 \mathrm{~min} ;{ }^{\mathrm{c}}$ procedure $C: 1.4$ eq diisopropylethylamine +1.25 eq electrophile +1 eq enone 11 in $\mathrm{CH}_{2} \mathrm{Cl}_{2}$ as solvent at $0^{\circ} \mathrm{C}$ for $30 \mathrm{~min} ;{ }^{\mathrm{d}}$ stereoselectivity estimated by ${ }^{1} \mathrm{H} \mathrm{NMR}$ analysing the product of the Diels-Alder reaction; only the $(Z E)$-diastereoisomer can react in a Diels-Alder reaction; ${ }^{\mathrm{e}}$ under the conditions of procedure $A$, the diene $\mathbf{1 0 b}$ could not be isolated, due to hydrolysis; the stereoselectivity was tentatively assigned based on the analysis of the raw material; ${ }^{f}$ diene 10c was isolated but not purified; ${ }^{\mathrm{g}}$ both diastereoisomers $(Z E)$ and $(E E)$ could be separated by chromatography on a silica gel column and the diasteriomeric ratio was estimated by ${ }^{19} \mathrm{~F} \mathrm{NMR} ;{ }^{\mathrm{h}}$ the synthesis of diene 10e was also carried out under kinetic conditions resulting in a better stereoselectivity 


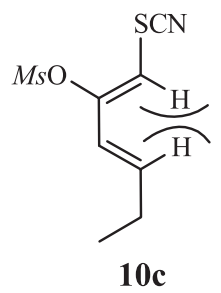

Scheme 7

99:1 (Scheme 5). As described in Table 1, four different electrophiles were used to trap the enol, applying three different experimental procedures (Table 1).

As predicted for the formation of the $1(Z), 3(E)$-diastereoisomers was favoured compared to the formation of the $1(E), 3(E)$-diastereoisomers. Using the procedure $B$ and mesyl chloride as an electrophile the best diastereoselectivity was observed $(d e>99 \%)$. A NOESY experiment showed a crosspeak between $\mathrm{H}-\mathrm{C}(1)$ and $\mathrm{H}-\mathrm{C}(4)$ (Scheme 7) proving the structure of compound 10c. The observed NOESY crosspeak is only compatible with the $s$-cis conformation of the $1(Z), 3(E)$-diastereoisomer.

Applying the conditions $D$ for the enolisation of enone 11 under kinetic control the dienes 10b and 10e were obtained. The lithium enolate $\mathbf{1 7}$ is formed under low-temperature conditions. The enolate is then quenched by various electrophiles to get the desired substituted 1-thiocyanatobuta-1,3-diene 10b and 10e. As indicated in Table 2 very good yields were obtained under these conditions. A satisfactory diastereoselectivity was observed with $T B D M S C l$ as an electrophile ( $d e=60 \%$ in favour of $1(Z), 3(E)$-diastereoisomer of the silylated 1-thiocyanatohexa-1,3-diene 10b). Using triflic anhydride as an electrophile, the influence of addition of $D M P U$ as a co-solvent on diastereoselectivity was studied. A good diastereoselectivity ( $d e=78 \%$ ) was observed without the use of the co-solvent. Addition of DMPU (20\% in $T H F)$ improved the diastereoisomeric excess to $d e=95 \%$.

Table 2. Stereoselectivity of the enolisation of enone $\mathbf{1 1}$ under kinetically controlled condition

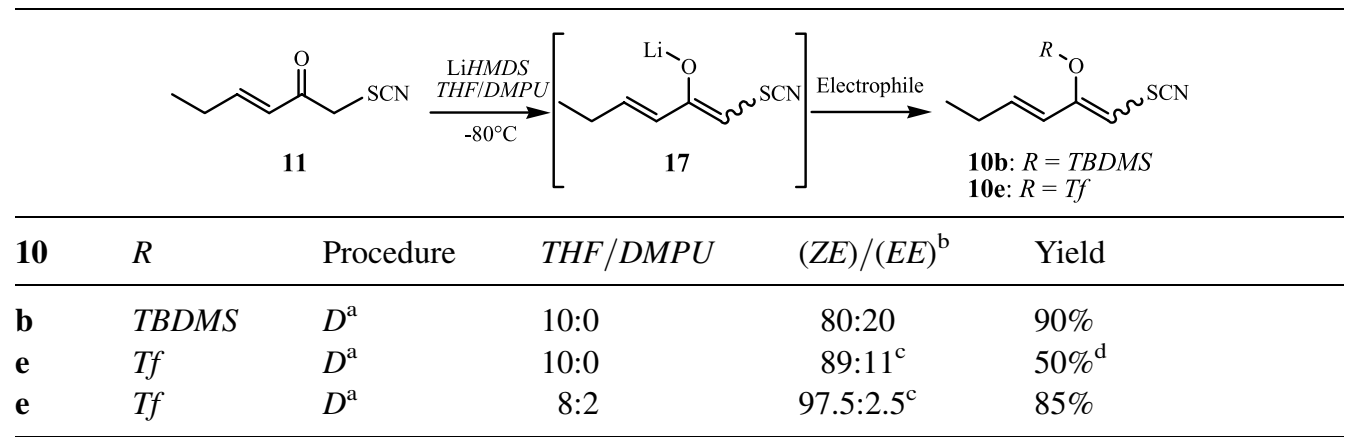

a Procedure $D$ : $1.1 \mathrm{eq} \mathrm{Li} H M D S$ in $T H F / D M P U$ as solvent at $-80^{\circ} \mathrm{C}$ for $45 \mathrm{~min}+1.1$ eq electrophile +1 eq enone 11 in $T H F$ as solvent at $0^{\circ} \mathrm{C}$ for $1 \mathrm{~h}$; ${ }^{\text {b }}$ stereoselectivity estimated by ${ }^{1} \mathrm{H}$ NMR analysing the product of the Diels-Alder reaction; only the (ZE)-diastereoisomer can react in a DielsAlder reaction; ${ }^{\mathrm{c}}$ the diastereomeric ratio was estimated by ${ }^{19} \mathrm{~F}$ NMR; ${ }^{\mathrm{d}}$ non optimised 


\section{Conclusions}

An efficient three-step synthesis of enone $\mathbf{1 1}$ has been developed giving $\mathbf{1 1}$ in $65 \%$ total yield. The stereoselectivity of the enolisation of $\mathbf{1 1}$ was studied under thermodynamically controlled conditions using different electrophiles to trap the enolate. Excellent diastereoisomeric excesses were observed and the best diastereoselectivity was found using mesyl chloride as an electrophile (de $>99 \%$ ) yielding the $1(Z), 3(E)$ 1-thiocyanatohexa-1,3-dien-2-yl methanesulfonate (10c). Under kinetically controlled conditions the 1-thiocyanatobuta-1,3-dienes $\mathbf{1 0 b}$ and $\mathbf{1 0 e}$ could be obtained. The addition of DMPU as a co-solvent was studied in the case of the 1-thiocyanatobuta-1,3-diene 10e. The diastereoselectivity $(d e=78 \%)$ could be improved using $D M P U(d e=95 \%)$. Efficient synthesis of five different substituted 1-thiocyanatobuta-1,3-dienes 10a-10e are reported in good total yields. Their efficiency in our Diels-Alder/[3,3] sigmatropic rearrangement tandem reaction will be studied in view of the development of a new total synthesis of (rac)-Ibogamine (6a).

\section{Experimental Part}

All moisture-sensitive reactions were carried out under $\mathrm{Ar}$ and $\mathrm{N}_{2}$ using oven-dried glassware. All reagents were of commercial quality if not specifically mentioned. Solvents were freshly distilled prior to use. Flash chromatography (FC): Brunschwig silica gel $60,0.032-0.063 \mathrm{~mm}$; under positive pressure. TLC: Merck precoated silica gel thin-layer sheets $60 \mathrm{~F} 254$, detection by UV and treatment with basic $\mathrm{KMnO}_{4}$ sol. Mp: Gallenkamp MFB-595. IR spectra: Perkin Elmer Spectrum One FT-IR, in $\mathrm{cm}^{-1}$. NMR spectra: Bruker Avance-400 (400 MHz $\left({ }^{1} \mathrm{H}\right), 162 \mathrm{MHz}\left({ }^{31} \mathrm{P}\right)$, and $\left.100 \mathrm{MHz}\left({ }^{13} \mathrm{C}\right)\right)$ and Varian Gemini-2000 $\left(188 \mathrm{MHz}\left({ }^{19} \mathrm{~F}\right)\right)$, at $\mathrm{rt}$, chemical shifts $\delta$ in ppm rel. to $\mathrm{SiMe}_{4}(=0 \mathrm{ppm})$ as internal reference, coupling constants $J$ in Hz. ESI-MS Finnigan LCQ. Elemental analyses of novel compounds agreed favourably with calculated values.

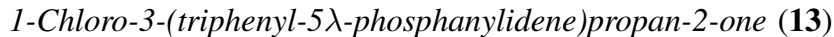

Triphenylphosphine $(52.90 \mathrm{~g}, 200.9 \mathrm{mmol})$ in $75 \mathrm{~cm}^{3}$ of dry $T H F$ was added to a solution of $25.12 \mathrm{~g}$ of 1,3-dichloroacetone $(197.8 \mathrm{mmol})$ in $25 \mathrm{~cm}^{3}$ of dry $T H F$. The mixture was heated to reflux for $4 \mathrm{~h}$ and the solvent was then removed. The resulting white salt was dissolved in $100 \mathrm{~cm}^{3}$ of methanol, and an aqueous solution $(1.55 \mathrm{M})$ of $10.48 \mathrm{~g}$ of $\mathrm{Na}_{2} \mathrm{CO}_{3}(98.9 \mathrm{mmol})$ was added. The mixture was allowed to stand for $30 \mathrm{~min}$ and the white precipitate was dried in air to provide a white powder of pure $\mathbf{1 3}$ (67.58 g, $191.6 \mathrm{mmol}, 97 \%)$. Ylide 13 has been described by Hudson et al. [22]. Mp 179-180 ${ }^{\circ} \mathrm{C}$ (Ref. [22] 178-179 ${ }^{\circ}$ ); $R_{f}=0.25\left(\mathrm{CH}_{2} \mathrm{Cl}_{2} / \mathrm{MeOH} 97 / 3\right) ;{ }^{31} \mathrm{P} \mathrm{NMR}\left(162 \mathrm{MHz}, \mathrm{CDCl}_{3}\right): \delta=16.9 \mathrm{ppm}$; ${ }^{1} \mathrm{H}$ NMR (400 MHz, $\left.\left.\mathrm{CDCl}_{3}\right): \delta=7.68-7.62\left(\mathrm{~m}, 6 \mathrm{H}, \mathrm{H}-5^{2}\right), 7.60-7.54\left(\mathrm{~m}, 3 \mathrm{H}, \mathrm{H}-5^{4}\right)\right), 7.50-7.45(\mathrm{~m}$, $\left.6 \mathrm{H}, \mathrm{H}-5^{3}\right), 4.28\left(\mathrm{~d},{ }^{2} J(3-\mathrm{P})=23.9 \mathrm{~Hz}, 1 \mathrm{H}, \mathrm{H}-3\right), 4.02$ (s, 2H, H-1) ppm; ${ }^{13} \mathrm{C} \mathrm{NMR}\left(100 \mathrm{MHz}, \mathrm{CDCl}_{3}\right)$ : $\delta=185.1(\mathrm{~s}, 1 \mathrm{C}, \mathrm{C}-2), 133.1\left(\mathrm{~s}, 6 \mathrm{C}, \mathrm{C}-5^{3}\right), 133.0\left(\mathrm{~s}, 3 \mathrm{C}, \mathrm{C}-5^{4}\right), 128.9\left(\mathrm{~d},{ }^{3} J\left(5^{2}-\mathrm{P}\right)=12.5 \mathrm{~Hz}, 6 \mathrm{C}, \mathrm{C}-5^{2}\right)$, $126.2\left(\mathrm{~d},{ }^{1} J\left(5^{1}-\mathrm{P}\right)=91.3 \mathrm{~Hz}, 3 \mathrm{C}, \mathrm{C}-5^{1}\right), 51.4\left(\mathrm{~d},{ }^{1} J(3-\mathrm{P})=114.5 \mathrm{~Hz}, 1 \mathrm{C}, \mathrm{C}-3\right), 47.3\left(\mathrm{~d},{ }^{3} J(1-\mathrm{P})=\right.$ $16.1 \mathrm{~Hz}, 1 \mathrm{C}, \mathrm{C}-1) \mathrm{ppm}$.

\section{1-Thiocyanato-3-(triphenyl-5 $\lambda$-phosphanylidene)propan-2-one $\left(\mathbf{1 4}, \mathrm{C}_{22} \mathrm{H}_{18} \mathrm{NOPS}\right)$}

Ylide $13(64.42 \mathrm{~g}, 182.6 \mathrm{mmol})$ in $300 \mathrm{~cm}^{3}$ of ethanol was added to a solution of $21.30 \mathrm{~g}$ of potassium thiocyanate $(219.1 \mathrm{mmol})$ in $350 \mathrm{~cm}^{3}$ of hot ethanol and $3.03 \mathrm{~g}$ of $\mathrm{KJ}(18.3 \mathrm{mmol})$ were added. The mixture was allowed to stir at $55^{\circ} \mathrm{C}$ for $5 \mathrm{~h}$ and cooled to rt. The potassium salts were filtered off, most 
of the solvent was evaporated in the rotavap, and $400 \mathrm{~cm}^{3}$ of $\mathrm{CH}_{2} \mathrm{Cl}_{2}$ were added. The potassium salts were filtered off again and washed with cold $\mathrm{CH}_{2} \mathrm{Cl}_{2}$. The resulting solution was concentrated to dryness to provide pure $14(65.75 \mathrm{~g}, 175.1 \mathrm{mmol}, 96 \%)$, mp $146-148^{\circ} \mathrm{C} . R_{f}=0.39\left(\mathrm{CH}_{2} \mathrm{Cl}_{2} / \mathrm{MeOH}\right.$ 97/3); ${ }^{31} \mathrm{P} \mathrm{NMR}\left(162 \mathrm{MHz}, \mathrm{CDCl}_{3}\right): \delta=16.1 \mathrm{ppm} ;{ }^{1} \mathrm{H} \mathrm{NMR}\left(400 \mathrm{MHz}, \mathrm{CDCl}_{3}\right): \delta=7.70-7.52$ $\left(\mathrm{m}, 9 \mathrm{H}, \mathrm{H}-5^{2}, \mathrm{H}-5^{4}\right), 7.51-7.42\left(\mathrm{~m}, 6 \mathrm{H}, \mathrm{H}-5^{3}\right), 3.96\left(\mathrm{~d},{ }^{2} J(3-\mathrm{P})=24.0 \mathrm{~Hz}, 1 \mathrm{H}, \mathrm{H}-3\right), 3.92(\mathrm{~s}, 2 \mathrm{H}$, $\mathrm{H}-1) \mathrm{ppm} ;{ }^{13} \mathrm{C} \mathrm{NMR}\left(100 \mathrm{MHz}, \mathrm{CDCl}_{3}\right): \delta=181.5\left(\mathrm{~d},{ }^{2} J(2-\mathrm{P})=3.1 \mathrm{~Hz}, 1 \mathrm{C}, \mathrm{C}=\mathrm{O}\right), 133.1(\mathrm{~d}$, $\left.{ }^{4} J\left(5^{3}-\mathrm{P}\right)=9.9 \mathrm{~Hz}, 6 \mathrm{C}, \mathrm{C}-5^{3}\right), 132.6\left(\mathrm{~d},{ }^{3} J\left(5^{4}-\mathrm{P}\right)=3.0 \mathrm{~Hz}, 3 \mathrm{C}, \mathrm{C}-5^{4}\right), 129.2\left(\mathrm{~d},{ }^{3} J\left(5^{2}-\mathrm{P}\right)=12.7 \mathrm{~Hz}, 6 \mathrm{C}\right.$, $\left.\mathrm{C}-5^{2}\right), 125.7\left(\mathrm{~d},{ }^{1} J\left(5^{1}-\mathrm{P}\right)=91.2 \mathrm{~Hz}, 3 \mathrm{C}, \mathrm{C}-5^{1}\right), 114.1(\mathrm{SCN}), 52.9\left(\mathrm{~d},{ }^{1} J(3-\mathrm{P})=108.5 \mathrm{~Hz}, 1 \mathrm{C}, \mathrm{C}-3\right), 43.1$ $\left(\mathrm{d},{ }^{3} J(1-\mathrm{P})=19.1 \mathrm{~Hz}, 1 \mathrm{C}, \mathrm{C}-1\right) \mathrm{ppm}$; IR $(\mathrm{KBr}): \bar{\nu}=2994,2153,1577,1548,1482,1438,1228,1108$, $764,747,719,692,518,507 \mathrm{~cm}^{-1}$.

\section{(E)-1-Thiocyanatohex-3-en-2-one (11, $\left.\mathrm{C}_{7} \mathrm{H}_{9} \mathrm{NOS}\right)$}

A solution of $44.35 \mathrm{~g}$ of ylide $14(118.1 \mathrm{mmol})$ in $86 \mathrm{~cm}^{3}$ of freshly distilled propanal is allowed to stir at $40^{\circ} \mathrm{C}$ for $6 \mathrm{~h}$ under $\mathrm{Ar}$ and cooled to rt. The mixture was concentrated and quickly filtered on a short silica gel column ( $200 \mathrm{~g} ; n$-hexane $\left./ \mathrm{CH}_{2} \mathrm{Cl}_{2} 1 / 1\right)$. The resulting brown oil was purified by bulb-to-bulb distillation $\left(100^{\circ} \mathrm{C}\right.$ at $\left.10^{-1} \mathrm{mbar}\right)$ to provide a malodorous pale yellow oil $(12.80 \mathrm{~g}, 82.5 \mathrm{mmol}, 70 \%)$. $R_{f}=0.42\left(\mathrm{CH}_{2} \mathrm{Cl}_{2}\right) ;{ }^{1} \mathrm{H} \mathrm{NMR}\left(400 \mathrm{MHz}, \mathrm{CDCl}_{3}\right): \delta=7.03\left(\mathrm{dt},{ }^{3} J(4-3)=16.0 \mathrm{~Hz},{ }^{3} J(4-5)=6.3 \mathrm{~Hz}\right.$, $1 \mathrm{H}, \mathrm{H}-4), 6.19\left(\mathrm{dt},{ }^{3} J(3-4)=16.0 \mathrm{~Hz},{ }^{4} J(3-5)=1.7 \mathrm{~Hz}, 1 \mathrm{H}, \mathrm{H}-3\right), 4.24$ (s, 2H, H-1), 2.31 (qdd, $\left.{ }^{3} J(5-6)=7.4 \mathrm{~Hz},{ }^{3} J(5-4)=6.3 \mathrm{~Hz},{ }^{4} J(5-3)=1.7 \mathrm{~Hz}, 2 \mathrm{H}, \mathrm{H}-5\right), 1.10\left(\mathrm{t},{ }^{3} J(6-5)=7.4 \mathrm{~Hz}, 3 \mathrm{H}, \mathrm{H}-6\right) \mathrm{ppm}$; ${ }^{13} \mathrm{C}-\mathrm{NMR}\left(100 \mathrm{MHz}, \mathrm{CDCl}_{3}\right): \delta=190.5(\mathrm{C}=\mathrm{O}), 153.6(\mathrm{C}-4), 126.5(\mathrm{C}-3), 111.9(\mathrm{SCN}), 42.7(\mathrm{C}-1)$, 25.9 (C-5), 11.9 (C-6) ppm; IR (film): $\bar{\nu}=2972,2935,2878,2158,1687,1626,1460,1392,1341$, $1297,1245,1180,1109,1081,1015,977,909 \mathrm{~cm}^{-1}$.

\section{1-Phenyl-2-thiocyanatoethanone (16b)}

According to the procedure described for $14,5.96 \mathrm{~g}$ of phenacyl chloride $(38.5 \mathrm{mmol})$ were treated with $4.70 \mathrm{~g}$ of $\mathrm{KSCN}(48.4 \mathrm{mmol})$ and $0.66 \mathrm{~g}$ of $\mathrm{KJ}(4.0 \mathrm{mmol})$ giving $5.90 \mathrm{~g}$ of $\mathbf{1 6 \mathbf { b }}(33.3 \mathrm{mmol}, 86 \%)$ as brown crystals. Thiocyanate $\mathbf{1 6 b}$ has been already isolated by Prakash et al. [29] as an oil. Recrystallisation in $n$-hexane/AcOEt $2 / 1$ gave needle shaped yellow crystals. Mp $81-82^{\circ} \mathrm{C} ; R_{f}=0.38$ (n-hexane/AcOEt 3/1); ${ }^{1} \mathrm{H}$ NMR $\left(400 \mathrm{MHz}, \mathrm{CDCl}_{3}\right): \delta=7.96\left(\mathrm{ddm},{ }^{3} J\left(3^{2}-3^{3}\right)=8.4 \mathrm{~Hz},{ }^{4} J\left(3^{2}-3^{4}\right)=\right.$ $\left.1.3 \mathrm{~Hz}, 2 \mathrm{H}, \mathrm{H}-3^{2}\right), 7.69\left(\mathrm{tt},{ }^{3} J\left(3^{4}-3^{3}\right)=7.4 \mathrm{~Hz},{ }^{4} J\left(3^{4}-3^{2}\right)=1.3 \mathrm{~Hz}, 1 \mathrm{H}, \mathrm{H}-3^{4}\right), 7.55\left(\mathrm{dd},{ }^{3} J\left(3^{3}, 3^{2}\right)=8.4 \mathrm{~Hz}\right.$, $\left.{ }^{3} J\left(3^{3}, 3^{4}\right)=7.4 \mathrm{~Hz}, 2 \mathrm{H}, \mathrm{H}-3^{3}\right), 4.76(\mathrm{~s}, 2 \mathrm{H}, \mathrm{H}-2) \mathrm{ppm} ;{ }^{13} \mathrm{C} \mathrm{NMR}\left(100 \mathrm{MHz}, \mathrm{CDCl}_{3}\right): \delta=190.9$ $(\mathrm{C}=\mathrm{O}), 134.9\left(\mathrm{C}-3^{4}\right), 134.1\left(\mathrm{C}-3^{1}\right), 129.3\left(\mathrm{C}-3^{3}\right), 128.6\left(\mathrm{C}-3^{2}\right), 112.0(\mathrm{SCN}), 43.1(\mathrm{C}-2) \mathrm{ppm}$; IR $(\mathrm{KBr}): \bar{\nu}=2937,2156,1678,1593,1448,1379,1326,1296,1202,998,757,687,630 \mathrm{~cm}^{-1}$.

\section{(Z)-1-Phenyl-2-thiocyanatovinyl methanesulfonate $\left(17, \mathrm{C}_{10} \mathrm{H}_{9} \mathrm{NO}_{3} \mathrm{~S}_{2}\right)$}

Triethylamine (141 mg, $1.4 \mathrm{mmol})$ was added to a solution of $177 \mathrm{mg}$ of $16 \mathbf{b}(1.0 \mathrm{mmol})$ in $5 \mathrm{~cm}^{3}$ of dry $\mathrm{CH}_{2} \mathrm{Cl}_{2}$ under Ar. After cooling to $0^{\circ} \mathrm{C}, 143 \mathrm{mg}$ of methanesulfonyl chloride $(1.25 \mathrm{mmol})$ were slowly introduced at $0^{\circ} \mathrm{C}(10 \mathrm{~min})$. After warming to $\mathrm{rt}$, the resulting mixture was stirred for additional $45 \mathrm{~min}$, diluted in $25 \mathrm{~cm}^{3}$ of $\mathrm{CH}_{2} \mathrm{Cl}_{2}$, and washed with $25 \mathrm{~cm}^{3}$ of $\mathrm{H}_{2} \mathrm{O}$ whose $\mathrm{pH}$ was adjusted to 3-5 with aqueous $\mathrm{HCl}(1 M)$. The organic layer was then washed with brine, dried $\left(\mathrm{MgSO}_{4}\right)$, and the solvent was evaporated to dryness to provide a green powder of a mixture of the two stereoisomers $(Z) /(E)(99 / 1) 17(102 \mathrm{mg}, 0.4 \mathrm{mmol}, 40 \%) . R_{f}=0.21$ ( $n$-hexane $/$ AcOEt 3/1); ${ }^{1} \mathrm{H} \mathrm{NMR}(400 \mathrm{MHz}$, $\left.\mathrm{CDCl}_{3}\right): \delta=7.56-7.50\left(\mathrm{~m}, 2 \mathrm{H}, \mathrm{H}-3^{3}\right), 7.50-7.42\left(\mathrm{~m}, 3 \mathrm{H}, \mathrm{H}-3^{2}, \mathrm{H}-3^{4}\right), 6.50(\mathrm{~s}, 1 \mathrm{H}, \mathrm{H}-2(E)), 6.44(\mathrm{~s}$, $1 \mathrm{H}, \mathrm{H}-2(Z)), 3.15$ (s, 3H, H-3(Z)), 3.01 (s, 3H, H-3(E)) ppm; ${ }^{13} \mathrm{C}$ NMR $\left(100 \mathrm{MHz}, \mathrm{CDCl}_{3}\right): \delta=151.0$ (C-1), $132.2\left(\mathrm{C}-3^{1}\right), 131.2\left(\mathrm{C}-3^{4}\right), 129.3\left(\mathrm{C}-3^{2}\right), 126.2\left(\mathrm{C}-3^{3}\right), 109.5(\mathrm{SCN}), 105.9(\mathrm{C}-2), 39.9(\mathrm{C}-3)$ ppm; IR (KBr): $\bar{\nu}=3068,3036,2934,2164,1681,1622,1354,1264,1172,1008,961,864,801,779$, $718,524,505 \mathrm{~cm}^{-1}$. 
General Procedures for the Synthesis of the Substituted 1-Thiocyanatobutadienes 10a-10e

Procedure A: To a stirred $0.6 \mathrm{M}$ solution of $2.2 \mathrm{eq}$ of triethylamine in diethylether at $\mathrm{rt}$ under Ar were added dropwise 2.0 eq of the corresponding electrophile. $1.0 \mathrm{eq}$ of $\mathbf{1 1}$ was then added dropwise to the solution for $5 \mathrm{~min}$. The resulting mixture was magnetically stirred at $\mathrm{rt}$ for $1 \mathrm{~h}$ and the solvent was evaporated. Freshly distilled $n$-pentane was added to the crude product, the salts were filtered off and washed with freshly distilled $n$-pentane again. After evaporating the $n$-pentane in vacuo, the product was isolated without further purification.

Procedure B: To a stirred $0.8 \mathrm{M}$ solution of $1.0 \mathrm{eq}$ of $\mathbf{1 1}$ in $\mathrm{CH}_{2} \mathrm{Cl}_{2}$ at $0^{\circ} \mathrm{C}$ under $\mathrm{Ar}$ were added $2.0-10.0 \mathrm{eq}$ of triethylamine. A $3.0 \mathrm{M}$ solution of $1.2-5.0 \mathrm{eq}$ of the corresponding electrophile in $\mathrm{CH}_{2} \mathrm{Cl}_{2}$ was then added dropwise to the solution for $30 \mathrm{~min}$. The resulting mixture was magnetically stirred at $0^{\circ} \mathrm{C}$ for $30 \mathrm{~min}$ and then diluted in $\mathrm{CH}_{2} \mathrm{Cl}_{2}$. The organic phase was then washed with $\mathrm{H}_{2} \mathrm{O}$, dried $\left(\mathrm{MgSO}_{4}\right)$, and concentrated in vacuo to obtain the raw product that was then purified by chromatography on a silica gel column.

Procedure $C$ : To a stirred $0.2 \mathrm{M}$ solution of $1.0 \mathrm{eq}$ of $\mathbf{1 1}$ in $\mathrm{CH}_{2} \mathrm{Cl}_{2}$ at $\mathrm{rt}$ under $\mathrm{Ar}$ were added $1.4 \mathrm{eq}$ of diisopropylethylamine. After cooling to $0^{\circ} \mathrm{C}, 1.25 \mathrm{eq}$ of the corresponding electrophile were added dropwise to the solution during $5 \mathrm{~min}$. The resulting mixture was magnetically stirred at $0^{\circ} \mathrm{C}$ for $30 \mathrm{~min}$ and then diluted in $\mathrm{CH}_{2} \mathrm{Cl}_{2}$. The organic phase was washed with saturated aqueous $\mathrm{NH}_{4} \mathrm{Cl}, \mathrm{H}_{2} \mathrm{O}$, dried $\left(\mathrm{MgSO}_{4}\right)$, and concentrated in vacuo to get the product that was purified by chromatography on a silica gel column.

Procedure D: A solution of 1.1 eq of Li bis(trimethyldisilyl)amide (1 $M$ in $T H F$ ) was diluted 3 times in a $T H F / D M P U$ mixture to get a $0.33 \mathrm{M}$ solution, which was cooled to $-90^{\circ} \mathrm{C}$. A $1.0 \mathrm{M}$ solution of $1.0 \mathrm{eq}$ of $\mathbf{1 1}$ in freshly distilled $T H F$ was then added dropwise while maintaining the temperature of the solution below $-80^{\circ} \mathrm{C}$. The orange solution was then magnetically stirred at $-85^{\circ} \mathrm{C}$ for $45 \mathrm{~min}$ and $1.1 \mathrm{eq}$ of the corresponding electrophile were added dropwise maintaining the temperature of the solution below $-80^{\circ} \mathrm{C}$. The temperature was then allowed to warm slowly to $0^{\circ} \mathrm{C}$ and the mixture was stirred for additional $1 \mathrm{~h}$ at $0^{\circ} \mathrm{C}$. After diluting three times the reactions mixture with $n$-hexane, the solution was poured onto saturated aqueous $\mathrm{NH}_{4} \mathrm{Cl}$. The organic phase was washed with $\mathrm{H}_{2} \mathrm{O}$ and brine, dried $\left(\mathrm{MgSO}_{4}\right)$, and concentrated in vacuo to get the product that was purified by chromatography on a silica gel column.

\section{Trimethyl((3E)-1-thiocyanatohexa-1,3-dien-2-yloxy)silane (10a, $\left.\mathrm{C}_{10} \mathrm{H}_{17} \mathrm{NOSSi}\right)$}

Procedure $A$ : Freshly distilled enone $11(0.40 \mathrm{~g}, 2.58 \mathrm{mmol})$ was reacted with $0.56 \mathrm{~g}$ of trimethylchlorosilane $(5.15 \mathrm{mmol})$ to obtain $\mathbf{1 0 a}$ as a yellow oil $(0.46 \mathrm{~g}, 2.02 \mathrm{mmol}, 78 \%)$ and $(Z E) /(E E)$ mixture (87/13). Compound 10a was extremely sensitive towards hydrolysis. ${ }^{1} \mathrm{H}$ NMR $\left(200 \mathrm{MHz}, \mathrm{CDCl}_{3}\right)$ : $\delta=6.65\left(\mathrm{dt},{ }^{3} J(3-4)=15.4 \mathrm{~Hz},{ }^{4} J(3-5)=1.1 \mathrm{~Hz}, 1 \mathrm{H}, \mathrm{H}-3(E E)\right), 6.37\left(\mathrm{dt},{ }^{3} J(4-3)=15.3 \mathrm{~Hz},{ }^{3} J(4-\right.$ $5)=6.2 \mathrm{~Hz}, 1 \mathrm{H}, \mathrm{H}-4(E E), 6.08\left(\mathrm{dt},{ }^{3} J(4-3)=15.3 \mathrm{~Hz},{ }^{3} J(4-5)=6.2 \mathrm{~Hz}, 1 \mathrm{H}, \mathrm{H}-4(Z E), 5.89\left(\mathrm{dt},{ }^{3} J(3-\right.\right.$ $\left.4)=15.4 \mathrm{~Hz},{ }^{4} J(3-5)=1.1 \mathrm{~Hz}, 1 \mathrm{H}, \mathrm{H}-3(Z E)\right), 5.25(\mathrm{~s}, 1 \mathrm{H}, \mathrm{H}-1(Z E)), 5.12(\mathrm{~s}, 1 \mathrm{H}, \mathrm{H}-1(E E)), 2.16$ (qdd, $\left.{ }^{3} J(5-6)=7.4 \mathrm{~Hz},{ }^{3} J(5-4)=6.3 \mathrm{~Hz},{ }^{4} J(5-3)=1.1 \mathrm{~Hz}, 2 \mathrm{H}, \mathrm{H}-5\right), 1.03\left(\mathrm{t},{ }^{3} J(6-5)=7.4 \mathrm{~Hz}, 3 \mathrm{H}, \mathrm{H}-6\right), 0.29$ (s, $\left.9 \mathrm{H}, \mathrm{H}-2^{1}\right) \mathrm{ppm}$.

\section{tert-Butyldimethyl((3E)-1-thiocyanatohexa-1,3-dien-2-yloxy)silane (10b, $\left.\mathrm{C}_{13} \mathrm{H}_{23} \mathrm{NOSSi}\right)$}

Procedure $D$ : Enone $11(0.47 \mathrm{~g}, 3.00 \mathrm{mmol})$ was reacted with a $1.0 \mathrm{M}$ solution of $0.50 \mathrm{~g}$ of tertbutyldimethylchlorosilane $(3.31 \mathrm{mmol})$ in freshly distilled $T H F$. After purification by quick filtration on silica gel with $n$-hexane/AcOEt 95/5, compound 10b was obtained as yellow oil $(0.73 \mathrm{~g}$, $2.71 \mathrm{mmol}, 90 \%)$ and $(Z E) /(E E)$ mixture $(80 / 20)$ that could not be separated. $R_{f}(Z E)=0.79$, $R_{f}(E E)=0.89\left(n\right.$-hexane/AcOEt 10/1); ${ }^{1} \mathrm{H} \mathrm{NMR}\left(400 \mathrm{MHz}, \mathrm{CDCl}_{3}\right): \delta=6.63\left(\mathrm{dt},{ }^{3} J(3-4)=15.2 \mathrm{~Hz}\right.$, $\left.{ }^{4} J(3-5)=1.6 \mathrm{~Hz}, 1 \mathrm{H}, \mathrm{H}-3(E E)\right), 6.42\left(\mathrm{dt},{ }^{3} J(4-3)=15.2 \mathrm{~Hz},{ }^{3} J(4-5)=6.5 \mathrm{~Hz}, 1 \mathrm{H}, \mathrm{H}-4(E E), 6.07(\mathrm{dt}\right.$, 
$\left.{ }^{3} J(4-3)=15.5 \mathrm{~Hz},{ }^{3} J(4-5)=6.5 \mathrm{~Hz}, 1 \mathrm{H}, \mathrm{H}-4(Z E)\right), 5.85\left(\mathrm{dt},{ }^{3} J(3-4)=15.5 \mathrm{~Hz},{ }^{4} J(3-5)=1.6 \mathrm{~Hz}, 1 \mathrm{H}, \mathrm{H}-\right.$ $3(Z E)), 5.23$ (s, $1 \mathrm{H}, \mathrm{H}-1(Z E)$ ), 5.10 (s, $1 \mathrm{H}, \mathrm{H}-1(E E)), 2.23\left(\mathrm{qdd},{ }^{3} J(5-6)=7.4 \mathrm{~Hz},{ }^{3} J(5-4)=6.5 \mathrm{~Hz}\right.$, $\left.{ }^{4} J(5-3)=1.6 \mathrm{~Hz}, 2 \mathrm{H}, \mathrm{H}-5(E E)\right), 2.13\left(\mathrm{qdd},{ }^{3} J(5-6)=7.4 \mathrm{~Hz},{ }^{3} J(5-4)=6.5 \mathrm{~Hz},{ }^{4} J(5-3)=1.6 \mathrm{~Hz}, 2 \mathrm{H}, \mathrm{H}-\right.$ $5(Z E)), 1.07\left(\mathrm{t},{ }^{3} J(6-5)=7.4 \mathrm{~Hz}, 3 \mathrm{H}, \mathrm{H}-6(E E)\right), 1.02\left(\mathrm{t},{ }^{3} J(6-5)=7.4 \mathrm{~Hz}, 3 \mathrm{H}, \mathrm{H}-6(Z E)\right), 1.00$ (s, 9H, H$\left.2^{3}(Z E)\right), 0.96\left(\mathrm{~s}, 9 \mathrm{H}, \mathrm{H}-2^{3}(Z E)\right), 0.20\left(\mathrm{~s}, 6 \mathrm{H}, \mathrm{H}-2^{1}(E E)\right), 0.19$ (s, 6H, H-2 $\left.{ }^{1}(Z E)\right)$ ppm; ${ }^{13} \mathrm{C}$ NMR $\left(100 \mathrm{MHz}, \mathrm{CDCl}_{3}\right): \delta=161.7$ (C-2(EE)), $157.7(\mathrm{C}-2(Z E)), 141.4$ (C-4(EE)), 137.8 (C-4(ZE)), 124.5 (C-3(ZE)), $120.7(\mathrm{C}-3(E E)), 112.0(\mathrm{SCN}(E E)), 111.5(\mathrm{SCN}(Z E)), 90.0$ (C-1(ZE)), 85.8 (C-1(EE)), 25.8 $\left(\mathrm{C}-2^{3}(Z E)\right), 25.7(\mathrm{C}-5(Z E)), 25.6\left(\mathrm{C}-2^{3}(E E)\right), 25.4(\mathrm{C}-5(E E)), 18.5\left(\mathrm{C}-2^{2}(E E)\right), 18.3\left(\mathrm{C}-2^{2}(Z E)\right), 13.0$ (C-6(ZE)), $13.0(\mathrm{C}-6(E E)),-3.4\left(\mathrm{C}-2^{1}(E E)\right),-4.4\left(\mathrm{C}-2^{1}(Z E)\right) \mathrm{ppm}$.

According to procedure $A$ using a $1.0 \mathrm{M}$ solution of tert-butyldimethylchlorosilane in diethylether, a $(Z E) /(E E)$ mixture $(63 / 37)$ of impure 10b was obtained.

(1Z,3E)-1-Thiocyanatohexa-1,3-dien-2-yl methanesulfonate $\left(10 \mathrm{c}, \mathrm{C}_{8} \mathrm{H}_{11} \mathrm{NO}_{3} \mathrm{~S}_{2}\right)$

Procedure $B$ : Enone $11(0.54 \mathrm{~g}, 3.48 \mathrm{mmol})$ in $35 \mathrm{~cm}^{3}$ of $\mathrm{CH}_{2} \mathrm{Cl}_{2}$ was reacted with a $0.5 \mathrm{M}$ solution of $0.50 \mathrm{~g}$ of methanesulfonylchloride $(4.35 \mathrm{mmol})$ in $\mathrm{CH}_{2} \mathrm{Cl}_{2}$ and $1.34 \mathrm{~g}$ of triethylamine $(13.23 \mathrm{mmol})$. Isolation according to $A$ to get $10 \mathrm{c}$ as yellow oil $(0.58 \mathrm{~g}, 2.49 \mathrm{mmol}, 71 \%) . R_{f}=0.20\left(\mathrm{CH}_{2} \mathrm{Cl}_{2}\right) ;{ }^{1} \mathrm{H}$ NMR $\left(400 \mathrm{MHz}, \mathrm{CDCl}_{3}\right): \delta=6.36\left(\mathrm{dtd},{ }^{3} J(4-3)=15.8 \mathrm{~Hz},{ }^{3} J(4-5)=6.6 \mathrm{~Hz},{ }^{5} J(4-1)=0.5 \mathrm{~Hz}, 1 \mathrm{H}\right.$, H-4), $6.18 \quad\left(\mathrm{dd},{ }^{5} J(1-4)=0.5 \mathrm{~Hz},{ }^{3} J(1-3)=0.5 \mathrm{~Hz}, 1 \mathrm{H}, \mathrm{H}-1\right), 5.97 \quad\left(\mathrm{dtd},{ }^{3} J(3-4)=15.8 \mathrm{~Hz},{ }^{4} J(3-\right.$ $\left.5)=1.3 \mathrm{~Hz},{ }^{4} J(3-1)=0.5 \mathrm{~Hz}, 1 \mathrm{H}, \mathrm{H}-3\right), 3.05 \quad\left(\mathrm{~s}, 3 \mathrm{H}, \mathrm{H}-2^{1}\right), 2.19 \quad\left(\mathrm{qdd},{ }^{3} J(5-6)=7.4 \mathrm{~Hz},{ }^{3} J(5-\right.$ $\left.4)=6.3 \mathrm{~Hz},{ }^{4} J(5-3)=1.3 \mathrm{~Hz}, 2 \mathrm{H}, \mathrm{H}-5\right), 1.03\left(\mathrm{t},{ }^{3} J(6-5)=7.4 \mathrm{~Hz}, 3 \mathrm{H}, \mathrm{H}-6\right) \mathrm{ppm} ;{ }^{13} \mathrm{C}-\mathrm{NMR}(100 \mathrm{MHz}$, $\mathrm{CDCl}_{3}$ ): $\delta=175.9(\mathrm{C}-2), 148.2(\mathrm{SCN}), 139.0(\mathrm{C}-4), 114.4(\mathrm{C}-3), 41.7\left(\mathrm{C}-2^{1}\right), 25.7(\mathrm{C}-5), 12.8(\mathrm{C}-6)$ ppm; ${ }^{1} \mathrm{H}$ NOESY: cross peak between $\delta=6.36$ and $6.18 \mathrm{ppm}$.

(3E)-1-Thiocyanatohexa-1,3-dien-2-yl 4-methylbenzenesulfonate (10d, $\left.\mathrm{C}_{14} \mathrm{H}_{15} \mathrm{NO}_{3} \mathrm{~S}_{2}\right)$

Procedure $B$ : Enone $11(0.31 \mathrm{~g}, 2.00 \mathrm{mmol})$ was reacted with a $0.4 M$ solution of $0.76 \mathrm{~g}$ of $p$-toluenesulfonyl chloride $(4.00 \mathrm{mmol})$ in $\mathrm{CH}_{2} \mathrm{Cl}_{2}$ and $2.02 \mathrm{~g}$ of triethylamine $(20.00 \mathrm{mmol})$. A $(\mathrm{ZE}) /(E E)$ mixture $(65 / 35)$ of impure $10 \mathrm{~d}(0.50 \mathrm{~g})$ was obtained by this procedure. $R_{f}=0.14(14 \%$ AcOEt in $n$-hexane). ESI-MS: $m / z=332.1[\mathrm{M}+\mathrm{Na}]^{+}$.

(3E)-1-Thiocyanatohexa-1,3-dien-2-yl trifluoromethanesulfonate (10e, $\left.\mathrm{C}_{8} \mathrm{H}_{8} \mathrm{~F}_{3} \mathrm{NO}_{3} \mathrm{~S}_{2}\right)$

Procedure $D$ : Enone $11(130 \mathrm{mg}, 0.84 \mathrm{mmol})$ was reacted with a $1.0 \mathrm{~cm}^{3}$ of a $1 M \mathrm{Li} H M D S$ solution diluted with $2 \mathrm{~cm}^{3}$ of a $7 / 3$ mixture of $T H F / D M P U$. Triflic anhydride $\left(0.16 \mathrm{~cm}^{3}, 0.94 \mathrm{mmol}\right)$ was added. Compound 10e was obtained as yellow oil $(205 \mathrm{mg}, 0.71 \mathrm{mmol}, 85 \%)$ and $(Z E) /(E E)$ mixture $(97.5 / 2.5)$. Both diastereoisomers could be separated by chromatography on a silica gel column using $n$-hexane $/ \mathrm{AcOEt}$ 95/5 as an eluant. ESI-MS: $m / z=310.0[\mathrm{M}+\mathrm{Na}]^{+}$.

l(Z),3(E)-Diastereoisomer: $R_{f}=0.34$ ( $n$-hexane/AcOEt 95/5); ${ }^{19} \mathrm{~F}$ NMR $\left(188 \mathrm{MHz}, \mathrm{CDCl}_{3}\right)$ : $\delta=-73.16 \mathrm{ppm} ;{ }^{1} \mathrm{H}$ NMR $\left(400 \mathrm{MHz}, \mathrm{CDCl}_{3}\right): \delta=6.32\left(\mathrm{dt},{ }^{3} J(4-3)=15.6 \mathrm{~Hz},{ }^{3} J(4-5)=6.5 \mathrm{~Hz}, 1 \mathrm{H}\right.$, $\mathrm{H}-4), 6.09(\mathrm{~s}, 1 \mathrm{H}, \mathrm{H}-1), 6.02$ (dt, $\left.{ }^{3} J(3-4)=15.6 \mathrm{~Hz},{ }^{4} J(3-5)=1.6 \mathrm{~Hz}, 1 \mathrm{H}, \mathrm{H}-3\right), 2.24$ (qdd, ${ }^{3} J(5-$ $\left.6)=7.4 \mathrm{~Hz},{ }^{3} J(5-4)=6.5 \mathrm{~Hz},{ }^{4} J(5-3)=1.6 \mathrm{~Hz}, 2 \mathrm{H}, \mathrm{H}-5\right), 1.07\left(\mathrm{t},{ }^{3} J(6-5)=7.4 \mathrm{~Hz}, 3 \mathrm{H}, \mathrm{H}-6\right) \mathrm{ppm}$; ${ }^{13} \mathrm{C}$ NMR $\left(100 \mathrm{MHz}, \mathrm{CDCl}_{3}\right): \delta=150.3(\mathrm{C}-2), 141.7(\mathrm{C}-4), 120.1(\mathrm{C}-3), 116.9(\mathrm{C}(\mathrm{SCN})), 108.4$ $\left(\mathrm{C}-2^{1}\right), 104.9$ (C-1), 25.8 (C-5), 12.6 (C-6) ppm.

l(E),3(E)-Diastereoisomer: $R_{f}=0.49$ ( $n$-hexane $\left./ \mathrm{AcOEt} 95 / 5\right) ;{ }^{19} \mathrm{~F}$ NMR $\left(188 \mathrm{MHz}, \mathrm{CDCl}_{3}\right)$ : $\delta=-73.65 \mathrm{ppm} ;{ }^{1} \mathrm{H}$ NMR $\left(400 \mathrm{MHz}, \mathrm{CDCl}_{3}\right): \delta=6.49\left(\mathrm{dt},{ }^{3} J(4-3)=15.4 \mathrm{~Hz},{ }^{3} J(4-5)=6.5 \mathrm{~Hz}, 1 \mathrm{H}\right.$, $\mathrm{H}-4), 6.35\left(\mathrm{dt},{ }^{3} J(3-4)=15.4 \mathrm{~Hz},{ }^{4} J(3-5)=1.5 \mathrm{~Hz}, 1 \mathrm{H}, \mathrm{H}-3\right), 6.10(\mathrm{~s}, 1 \mathrm{H}, \mathrm{H}-1), 2.32\left(\mathrm{~m},{ }^{3} J(5-6)=7.4 \mathrm{~Hz}\right.$, $\left.{ }^{3} J(5-4)=6.5 \mathrm{~Hz},{ }^{4} J(5-3)=1.5 \mathrm{~Hz}, 2 \mathrm{H}, \mathrm{H}-5\right), 1.11\left(\mathrm{t},{ }^{3} J(6-5)=7.4 \mathrm{~Hz}, 3 \mathrm{H}, \mathrm{H}-6\right) \mathrm{ppm} ;{ }^{13} \mathrm{C}$ NMR $\left(100 \mathrm{MHz}, \mathrm{CDCl}_{3}\right): \delta=151.3(\mathrm{C}-2), 144.8(\mathrm{C}-4), 126.0(\mathrm{SCN}), 116.9(\mathrm{C}-3), 108.3\left(\mathrm{C}-2^{1}\right), 103.0$ (C-1), 26.3 (C-5), 12.6 (C-6) ppm. 
The same procedure without the use of $D M P U$ led to a $(Z E) /(E E)$ mixture $(89 / 11)$ of 10e in $50 \%$ yield which was not optimised.

Procedure $C$ : Enone $11(0.40 \mathrm{~g}, 2.57 \mathrm{mmol})$ was reacted with triflic anhydride. Compound 10e was then purified by chromatography on a silica gel column by using $\mathrm{CH}_{2} \mathrm{Cl}_{2}$ as an eluant to get a $(Z E) /(E E)$ mixture $(65 / 35)(0.53 \mathrm{~g}, 1.85 \mathrm{mmol})$ in $72 \%$ yield which was not optimised.

\section{Acknowledgements}

NMR Spectra $(400 \mathrm{MHz})$ were measured by H. Bursian and Dr. C. Saturnin, mass spectra by $N$. Mottier and J. Jean-Denis, $\mathrm{CHN}$ analyses were made in the Ecole d'ingénieurs et d'architectes de Fribourg. We thank the University of Neuchâtel and the Swiss National Science Foundation for financial support.

\section{References}

[1] Tietze LF (1996) Chem Rev 96: 115

[2] Ho TL (1993) Tandem Organic Reactions. Wiley, New York

[3] Nicolaou KC, Montagnon T, Snyder SA (2003) Chem Comm 551

[4] Neuschütz K, Velker J, Neier R (1998) Synthesis 227

[5] Schöpfer J, Marquis C, Pasquier C, Neier R (1994) J Chem Soc Chem Comm 1001

[6] Trost BM, Genêt JP (1976) J Am Chem Soc 98: 8516

[7] Trost BM, Godleski SA, Genêt JP (1978) J Am Chem Soc 100: 3930

[8] Popik P, Skolnick P (1998) Pharmacology of Ibogaïne and Ibogaïne-Related Alkaloïds. In: Cordell GA (ed) The Alkaloïds, vol 52. Academic Press, San Diego, p 197

[9] Cappendijk SLT, Dzoljic MR (1993) Eur J Pharmacol 241: 261

[10] Glick SD, Kuehne ME, Raucci J, Wilson TE, Larson D, Keller RW, Carlson JN (1994) Brain Res 657: 14

[11] Alper KR, Lotsof HS, Frenken GMN, Luciano DJ, Bastiaans J (1999) Am J Addictions 8: 234

[12] Büchi G, Coffen DL, Kocsis K, Sonnet PE, Ziegler FE (1965) J Am Chem Soc 87: 2073

[13] Nagata W, Hirai S, Kawata K, Okumura T (1968) J Am Chem Soc 90: 1650

[14] Ikezaki M, Wakamatsu T, Ban Y (1968) Chem Comm 88

[15] Rosenmund P, Haase WH, Bauer J, Frische R (1975) Chem Ber 108: 1871

[16] Rahman A-U, Beisler JA, Harley-Mason J (1980) Tetrahedron 36: 1063

[17] Huffmann JW, Shanmugasundaram G, Sawdaye R, Raveendranath PC, Desai RC (1985) J Org Chem 50: 1460

[18] Kuehne ME, Reider PJ (1985) J Org Chem 50: 1464

[19] Imanishi T, Yagi N, Hanaoka M (1985) Chem Pharm Bull 33: 4202

[20] Henry KJ Jr, Grieco PA, DuBay WJ (1996) Tetrahedron Lett 37: 8289

[21] White JD, Choi Y (2000) Org Lett 2: 2373

[22] Hudson RF, Chopard PA (1963) J Org Chem 28: 2446

[23] Sapi A, Fetter J, Lempert K, Kajtar-Peredy M, Czira G (1997) Tetrahedron 53: 12729

[24] Tanigushi M, Takeyama Y, Fugami K, Oshima K, Utimoto K (1991) Bull Chem Soc Japan 64: 2593

[25] Robinson EA, Gillespie JR (1980) J Chem Educ 57: 329

[26] Rassat A (2004) Phys Chem Chem Phys 6: 232

[27] Wintner CE (1987) J Chem Educ 64: 587

[28] Vogel E, Caravatti G, Franck P, Aristoff P, Moody C, Becker A-M, Felix D, Eschenmoser A (1987) Chem Lett 219

[29] Prakash O, Harpreet K, Batra H, Rani N, Singh SP, Moriarty RM (2001) J Org Chem 66: 2019 